\title{
RELATIONSHIPS BETWEEN ACTORS OF TRANSBORDER CO-OPERATION POLISH-GERMAN BORDERLAND CASE STUDY
}

\author{
SYLWIA DOŁZBŁASZ, ANDRZEJ RACZYK \\ Institute of Geography and Regional Development \\ University of Wrocław \\ Kuźnicza 49/55, 50-138 Wrocław, Poland \\ e-mail: sylwia@vm.pl andrzej.raczyk@geogr.uni.wroc.pl
}

\begin{abstract}
The study allowed to determine the level of development of transborder co-operation connections, thematic scope and the strength of connections between the partners in the Polish-German border areas. The analysis of actors helped identify institutional settings on both sides of the border (levels of co-operation according to the level of territorial unit and similarity between actors in terms of their formal-legal status). The analysis also covered the spatial aspect of the existing network of connections. The study takes into consideration mutual relationships between the analyzed features. The analysis revealed similarities between institutional network of the co-op erating authors and a relatively limited strength of connections. Moreover, the study showed that the type of actors, the strength of connections and thematic scope of jointly realized projects were strongly interconnected.
\end{abstract}

Key word: cross-border co-operation, transborder connctions, borderland region

\section{INTRODUCTION}

In the borderland areas in which new and old EU Member States co-exist, the moment of accession brought about significant changes in transborder co-operation (above all concerning formal legal arrangements). As a result, the previous structures of co-operation underwent a major transformation. Therefore, the shaping of connections between actors of co-operation in such border areas became an important issue. The date of Poland's accession to the EU (2004) and the intensity of PolishGerman transborder co-operation makes it a good example for the analysis of this phenomenon. 
Research conducted to date in Poland has concentrated mainly on the analysis of co-operation determinants and the assessment of realized activities. To a relatively short extent they dealt with the issue of effects of this co-operation and relationships between its actors, mainly due to difficulties in accessibility to relevant empirical material. Furthermore, despite a great number of studies concerning borderland areas, a significant part of them is incomplete in terms of their spatial range (concerning areas on one side of the border only, and not the whole borderland area) and thematic scope (e.g. concerning only tourism). The shaping of relationships between partners seems to be a very significant element of transborder co-operation development and in particular in the context of network relationships (Strihan 2008). This is as these relationships may define, among other things, thematic scope, durability and effectiveness of co-operation as well as character and strength of relationships. As a result, it may determine future directions in the development of cross-border relationships. Recognition of the above-mentioned regularities should be of significance in the selection of regional policy instruments oriented towards territorial co-operation. This study is an attempt at broadening knowledge in this field based on empirical research.

The objective of this paper was to determine the level of development of transborder co-operation connections in the Polish-German border area, including:

- the analysis of thematic scope of co-operation,

- identification of institutional settings on both sides of the border (mainly the analysis of actors in terms of similarity between their types),

- the analysis of the strength of connections between the partners,

- the analysis of the spatial aspect of the existing network of connections,

- the analysis of mutual relationships between the analyzed features.

The study comprises a verification of the hypothesis assuming that:

- the relationships are between actors of the same type,

- the strength depends on the type of actor,

- the strength depends on the similarity of the type of cooperating actors.

The research covered the Polish-German borderland area eligible for support under border co-operation programme Interreg III A in the programme period 2004-2006 (the actual realization period was 2004-2009).

The research uses data from Ministry of Regional Development as well as data obtained directly from programme beneficiaries. The analyzed data concerned Polish beneficiaries of the programmes and their partners on the German side as regards type, location and the strength of co-operation. Additionally, the type of project (according to intervention category) was considered. Due to the fact that gathering the required and complete information turned out to be impossible for all projects (there were 300 projects realized within Polish-German Interreg III A programmes), the analysis covered 184 projects (which is over 60\%). 


\section{CO-OPERATION DETERMINANTS}

The area of Polish-German borderland, due to its multi-aspect character and changeability of determinants may be a very good example of borderland co-operation development in the process of European integration. This is the result of the following phenomena (Ciok 2004; Jańczak 2008):

- rich co-operation history in the post-war period, with periods of intensive co-operation development and its limitations (mainly administrative, caused by political considerations),

- one of the greatest levels of disproportion among EU-Member States in economic development between areas on both sides of the border,

- marginal character of both borderland areas in the domestic setting (both in the case of Poland and Germany),

- diversity of expectations concerning potential co-operation directions on both sides of the border,

- asymmetry in accessibility to funds supporting co-operation development on both sides of the border in the period before 2004 (the date of Poland's accession to the EU), - significant role of the border as a barrier (Koschatzky 2000), despite Poland's accession to the EU (2004) and Poland's entry into the Schengen zone (2007), mainly due to environmental determinants (the river border with lack of bridges),

- an important role of historical factors,

- high level of social and cultural diversity.

The existing determinants make borderland co-operation development at PolishGerman borderland multidimensional. The results of the research conducted so far indicate a lack of one, dominant integrating factor which could form the main node of connection creation - in cases of other borders such a factor is e.g. tourism (Dołzbłasz and Raczyk 2007).

\section{CHARACTERISTICS OF TRANSBORDER CONNECTIONS}

For the purposes of this study, an analysis of transborder co-operation projects was performed concerning the projects submitted by Polish entities under Interreg III A programme. Thus, the research into co-operation relationships covered Polish actors as well as German actors indicated by them. In most cases, Polish actors had only one partner on the German side (95\%). More than one partner was reported in less than $4 \%$ and lack of partner in $1 \%$ of cases. Consideration needs to be made for the fact that connection shaping was based on two fundamental procedures:

- searching for a partner for the purpose of project realization under Interreg III A, - using previous partner relationships for the realization of the project under Interreg III A.

In the first case, the Interreg III A Community Initiative programme generated the creation of new transborder connections. From this point of view it could serve as 
an important instrument of co-operation development at its initial stage. At the same time, it was connected with the risk that the end of the project may also mean the end of co-operation between actors (above all in the situation when co-operation was treated not as the aim, but the means to obtain additional funds from the EU) (Hall 2008). The weaker the relationship between the partners during project realization, the higher the risk was.

In the latter case, the Interreg programme mainly served the purpose of deepening already existing co-operation and was one of many incentives to undertake common activities as well as a potential source of their funding.

As regards Polish-German border areas, the empirical material gathered did not allow to unambiguously determine which of the above-mentioned ways of creating connections prevailed. This problem requires separate, extensive research which could determine the actual reasons for starting co-operation and the evolution of partners' behaviour over time (above all concerning increase or decrease in the strength of mutual relationships) depending on the changing determinants ${ }^{1}$. However, regardless of the partners' intentions, the scope of transborder effect of undertakings realized by partners on both sides of the border, which is subject of the analysis described in this paper, allows to determine the strength of mutual connections.

A characteristic feature of the analysed population of partners on both sides of the Polish-German border was their general similarity in terms of legal/institutional structure $^{2}$ (Figure 1). Important differences concern a significantly greater participation of non-government organisations and business environment institutions among German actors and municipalities among Polish actors. Institutional arrangement on the Polish side was characterised by a significantly greater concentration and dominance of territorial self-governments. This affects the character of co-operation between them.

From the point of view of the subject of the paper, it is important whether the actors realizing particular projects were of the same type. The results of the research indicate that similarity, or lack of similarity was changeable and dependent on the type of the Polish beneficiary (Table 1). For example, as regards scientific institutions, in over $70 \%$ of cases their German partner was also a scientific institution. Apart from them, a very high level of similarity of types was characteristic of territorial self-government units. However, in the group of cultural institutions, NGOs and schools, German partners were diversified. Co-operation with a German partner of the same type usually was the result of the specific character of their activity (e.g. scientific institutions, national parks) and formal arrangements (e.g. territorial self-government units).

Lack of similarities between types of actors on both sides of the border may mean that many institutions, mainly from the private sector, are searching for their place

\footnotetext{
${ }^{1}$ Research into this field was undertaken under a separate research project concerning durability of partnerships in transborder co-operation (project financed by Ministry of Science and Higher Education, authors: Szmigiel K., Dziemianowicz W., Dołzbłasz S.).

2 Topology of actors was based on Polish legal acts. This topology was used during structural funds realization in the programme period 2004-2006 in Poland (Dołzbłasz and Raczyk 2010).
} 


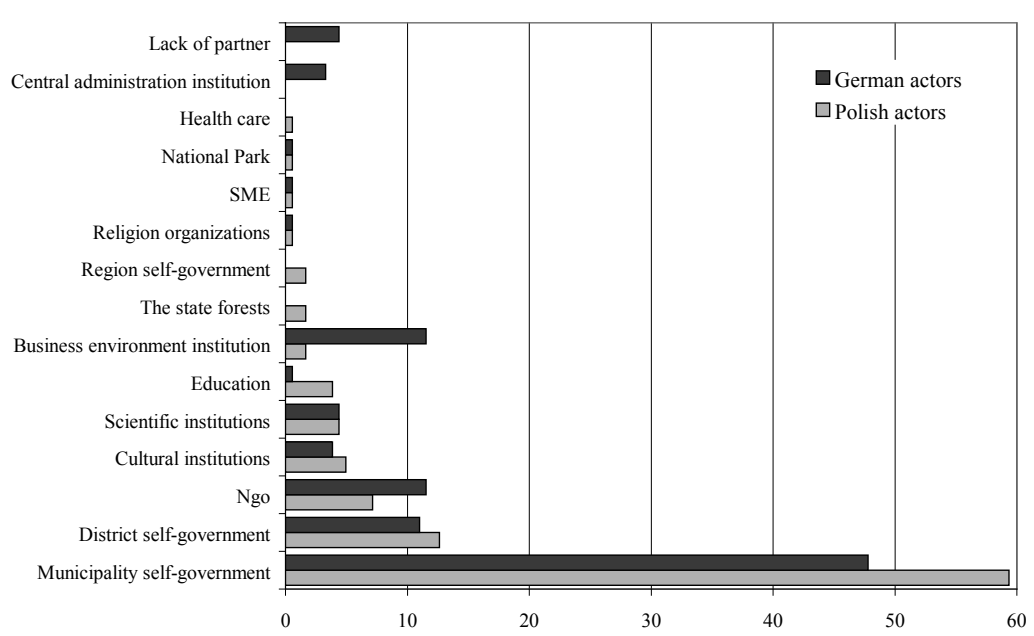

Figure 1. The actors' structure in the Polish-German borderland within the framework of Interreg III A programmes (\%)

Source: Figures 1-4 own study.

and role in the Polish-German borderland area (thematic scope of activities and cooperating entities). This means that from the point of view of regional policy, promotion of a particular type of co-operation actors on one side of the border may affect the structure of actors' type on the other. Therefore, it may be a way of extending or strengthening the present institutional setting of areas of co-operation. As a result, in the situation of lack of similarity between the types of actors on both sides of the border, their co-operation may have a spontaneous character, which means that in some cases it will be short-lived. This stems from the fact that in such cases, what links different units and institutions is mainly the realization of particular, defined tasks (task approach). However, if the types of actors are similar on both sides of the border, the mutual relationships may take the form of more formal connections, which are usually more long-lasting. In these cases they are mostly based on similarity of purposes as well as similarity of institutions and therein resulting formal / legal co-operation conditions (focus on institutions). In either situation, similarities (lack of similarities) between types of actors had significant implications for other aspects of co-operation.

For the assessment of the strength of the connection between actors, this study uses information concerning partners' involvement in the realization of particular projects. This constituted an important element of the assessment of transborder effect of the projects. This allowed to identify five co-operation levels:

- lack of partner on the other side of the border,

- joint preparation of the project,

- joint realization of the project,

- joint preparation and realization of the project,

- joint preparation, realization and financing of the project. 
Table 1. Compatibility of partners in the Polish-German borderland (\%)

\begin{tabular}{|c|c|c|c|c|c|c|c|c|c|}
\hline \multirow[b]{2}{*}{$\begin{array}{l}\text { Polish actor } \\
\text { type }\end{array}$} & \multicolumn{9}{|c|}{ German actor type } \\
\hline & $\begin{array}{c}\text { Central } \\
\text { admini- } \\
\text { stration } \\
\text { institution }\end{array}$ & $\begin{array}{l}\text { Scienti- } \\
\text { fic insti- } \\
\text { tutions }\end{array}$ & $\begin{array}{l}\text { Business } \\
\text { environ- } \\
\text { ment in- } \\
\text { stitution }\end{array}$ & $\begin{array}{c}\text { Cultural } \\
\text { institu- } \\
\text { tions }\end{array}$ & $\begin{array}{c}\text { Munici- } \\
\text { pality } \\
\text { self-go- } \\
\text { vernment }\end{array}$ & $\begin{array}{l}\text { District } \\
\text { self- } \\
\text { govern- } \\
\text { ment }\end{array}$ & NGO & $\begin{array}{c}\text { National } \\
\text { Park }\end{array}$ & Total \\
\hline $\begin{array}{l}\text { Scientific } \\
\text { institutions }\end{array}$ & & 75 & 25 & & & & & & 100 \\
\hline $\begin{array}{l}\text { Business } \\
\text { environment } \\
\text { institution }\end{array}$ & & & 100 & & & & & & 100 \\
\hline $\begin{array}{l}\text { Cultural } \\
\text { institutions }\end{array}$ & 33 & & & 45 & 22 & & & & 100 \\
\hline $\begin{array}{l}\text { Municipality } \\
\text { self-government }\end{array}$ & 3 & 1 & 7 & 4 & 72 & 4 & 9 & & 100 \\
\hline $\begin{array}{l}\text { District } \\
\text { self-government }\end{array}$ & 6 & & 11 & & 11 & 72 & & & 100 \\
\hline $\begin{array}{l}\text { Region } \\
\text { self-government }\end{array}$ & & & & & 67 & & 33 & & 100 \\
\hline The state forests & & & & & 33 & & 67 & & 100 \\
\hline NGO & & 8 & 23 & & 23 & 8 & 38 & & 100 \\
\hline National Park & & & & & & & & 100 & 100 \\
\hline Education & & & 57 & & & & 43 & & 100 \\
\hline
\end{tabular}

Source: own study.

It needs to be stressed, however, that each of the above-mentioned levels was internally diversified e.g. sometimes joint preparation consisted in passing information concerning the undertaking and its acceptance by the partner, and sometimes it was connected with the actual joint preparation and project work.

The results of the study revealed that the type of Polish beneficiary was largely connected with the strength of transborder effect. Projects realized by schools, business environment institutions, NGOs and scientific institutions exhibited the highest level of transborder effect understood as the strength of transborder connections. The lowest level was observed among territorial self-government units.

One of the most surprising conclusions resulting from the observation of relationships between types of partners on both sides of the border and the quality of transborder co-operation is the fact that the lack of similarity between actors resulted in noticeable improvement in its quality (Figure 2). This was reflected in a significant share of jointly prepared and realized projects. It seems that co-operation between partners of various types translates into an increased transborder effect mainly because only strong mutual relationships could lead to such co-operation between these partners. Therefore, an important role may be played here by a barrier connected with co-operation initiation (greater in the case of lack of 
similarity between types of institutions on both sides of the border, smaller - among institutions of similar type). Compatibility of types was probably reflected in a more permanent character of mutual relationship and greater probability of formalizing it. Therefore, it raised the probability of a discrepancy between the declared and the actual co-operation level, which translated into its relatively lower strength. From the point of view of the current regional policy and integration processes occurring in the border areas it would be good to try to combine the increase in effectiveness of the realized co-operation and stability of its structures (including institutional ones). In this context, stable and formalized connections between partners should form the skeleton facilitating closer co-operation. In other words, stable structures should help strengthen and initiate the creation of "spontaneous" structures.

It cannot be ruled out, of course, that the observed relationships concern only the initial stage of the shaping of common transborder region and in the future similarity between partners will translate into greater strength of mutual relationships than at present. This requires constant monitoring of the processes taking place in the border region.

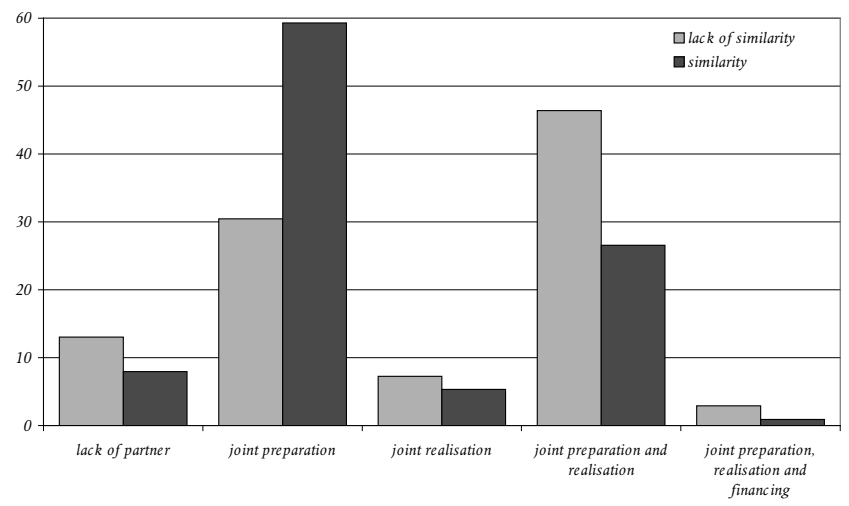

Figure 2. Similarity between types of actors and strenght of relationships in the Polish-German borderland

In the context of the above-presented relationships of similarity between actors, the question has arisen whether this similarity plays an important role in different types of projects (Figure 3). Types of projects according to thematic scope were created on the basis of classification of structural fund intervention category, used for monitoring and evaluation of, among others, Interreg III A programme (see OJ L 63/21, 3.3.2001). In most types of projects, similarity between actors did not play a significant role. An exception to this rule are projects in the field of entrepreneurship support, human resources and environmental protection infrastructure. Soft projects are dominated by co-operation between various types of actors. This results from the fact that issues of this type may be realized by many institutions. In infrastructure projects (hard) similarities between actors are greater, which is caused by 
stiff institutional arrangements concerning basic infrastructure (e.g. municipalities in the scope of the sewage system).

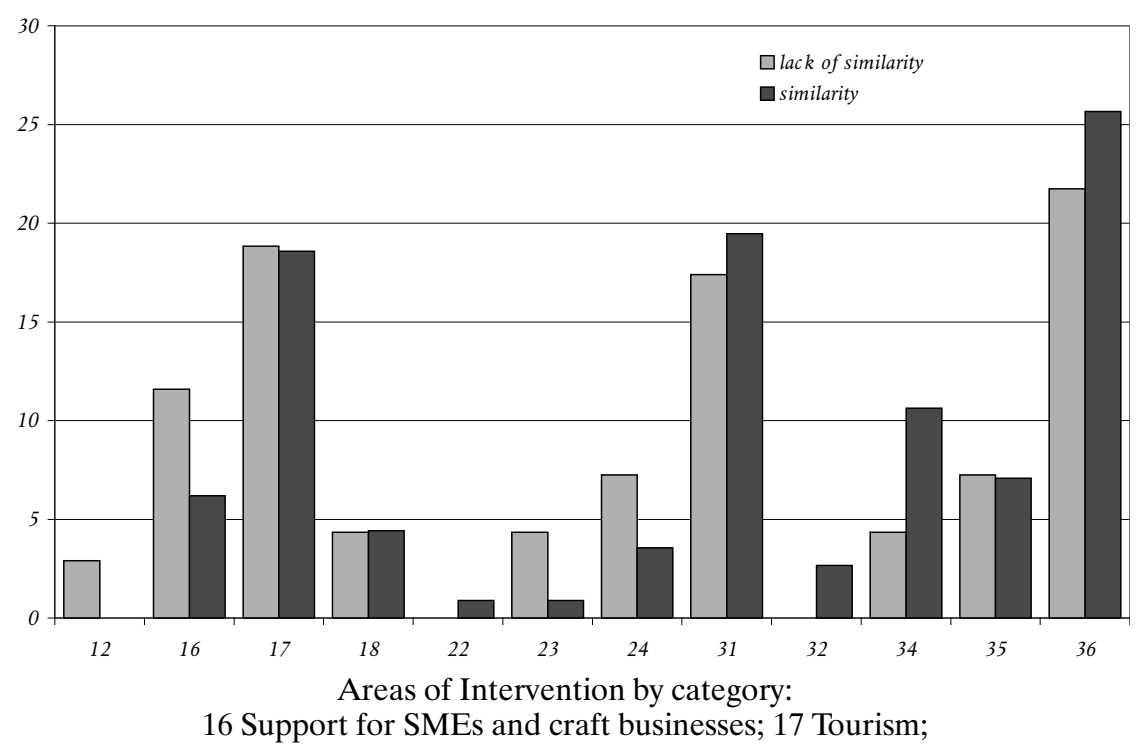

18 Research, technological development and innovation; 22 Labour market policy;

23 Developing educational and vocational training; 24 Workforce flexibility;

31 Transport infrastructure; 32 Telecommunications infrastructure and information society;

34 Environmental infrastructure; 35 Spatial planning and rehabilitation;

36 Social and public health infrastructure.

Figure 3. Types of projects according to similarities between types of actors in the Polish-German borderland (\%)

Apart from types of actors the strength of connections in the Polish-German borderland was largely influenced by frequency of occurrence of actors. In the analysis, the population of Polish actors was divided into two groups: projects of multiple actors and projects of one-time actors. The 182 projects on the Polish side were realized by 137 actors (among them $22 \%$ of actors with more than one project). There were 132 German partners assigned to Polish projects (6\% of projects didn't have a German partner, and $19 \%$ of German partners took part in more than one project). As expected, the projects which were realized by multiple actors had greater transborder effect. This indicates specialization of some actors in transborder co-operation projects. They realize more projects, which are also of better quality (the strength of their relationship is greater).

The study revealed that in the borderland area, on the Polish side there are observable areas of actors' concentration in the largest cities and their surroundings - Jelenia Góra, Zielona Góra, Gorzów Wielkopolski, Szczecin (Figure 4). On the German side, there is no such visible partner concentration. It was also observed that in many cases, Polish actors who were located near the border had their German partners also near the border. In the case of actors with locations 
further from the border, the distance factor did not play an important role. Moreover, in some cases they had partners outside the support area of Interreg III A. Preliminary analysis does not indicate that the distance between actors affects the strength of connections between them (it seems that there was no such relationship). Identification of mutual relationships in the network of connection between actors requires further, more in-depth analyses with consideration of the types of particular actors and thematic scope of their co-operation as it is hard to foresee at present how permanent the present network of co-operation is.

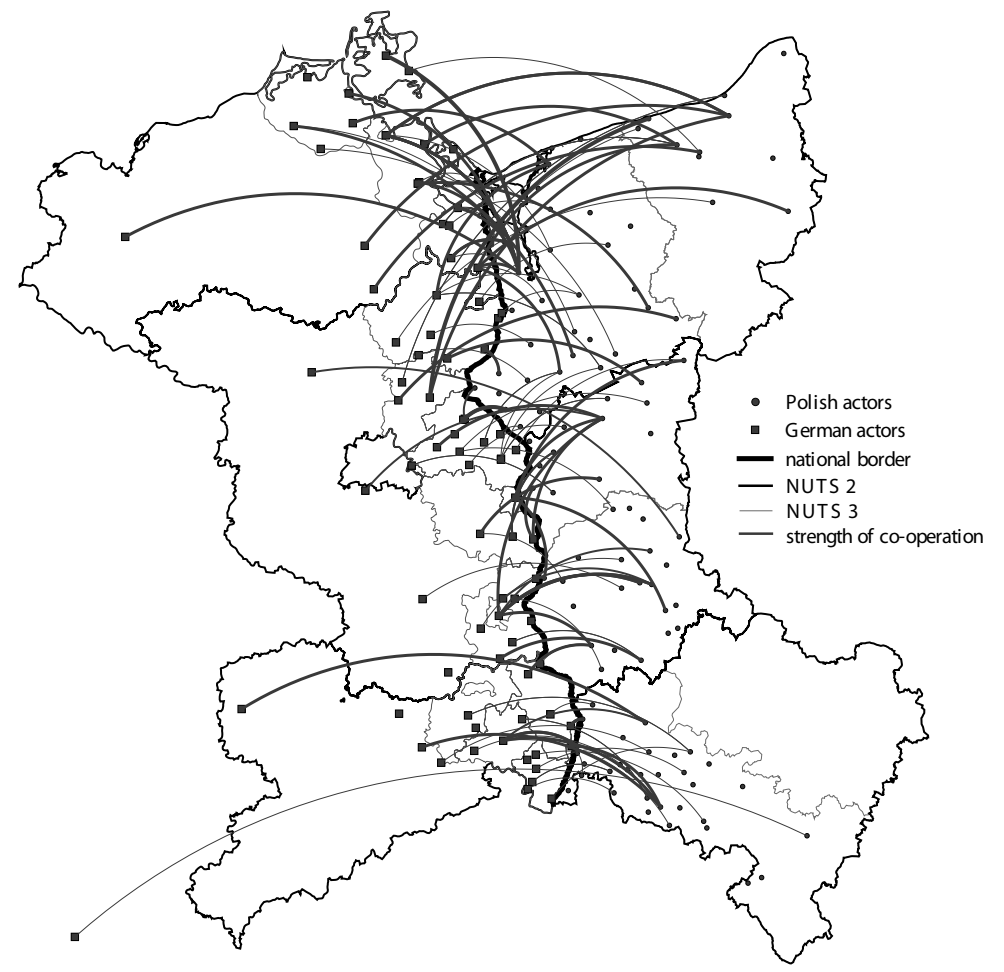

Figure 4. Connections between Polish and German actors within the framework of Interreg III A in the Polish-German borderland

\section{CONCLUSIONS}

The analysis revealed similarity between institutional setting of co-operating actors and relatively low strength of mutual connections. Although institutional setting structure on both sides of the border is similar, the shaping of new connections between actors is not only conditioned by similarity of their types. In nearly $40 \%$ of pairs, they were created by different types of actors. Thus, the hypothesis that the crucial factor of connection shaping is similarity of actors' types was not confirmed. It can facilitate initiation of co-operation, but does not determine it. 
The study confirmed that the strength of connections varies according to type of actor. It needs to be stressed, however, that institutions of "authority" (e.g. territorial self-government units) are characterised by a relatively lower strength of connections (measured by transborder effect of the realized undertakings) with partners on the other side of the border. This is probably the result of a high risk of over formality and bureaucracy of jointly realized activities. The strongest connections were observed among actors from NGOs group, business environment units and scientific institutions. However, they were relatively poorly represented in the beneficiary structure.

Although similarities between type of actors have largely influenced the strength of transborder connections, paradoxically it was the lack of similarity (and not the similarity between the actors) which caused a relative increase in the quality of co-operation. This factor defined the character of co-operation (activity-oriented vs. institution-oriented). As a result, permanent, formalized connections between actors of the same type should form the basis facilitating the establishment of stronger relationships, which would have a more individual character (between different types of actors). This confirms the need to increase both the number as well as types of actors involved in transborder co-operation.

Diversity of actors translates into broadening the range of realized activities. Different types of actors on both sides of the border usually realized projects from outside the co-operation mainstream (e.g. soft projects). Therefore, in the context of aiming at multi-thematic co-operation it is necessary to engage the largest possible number of diverse actors. This will favour the activation of local communities and grass-roots initiatives (community co-operation). At the same time, it will prevent limitation of co-operation to only "top-down" activities, which, due to the special character of transborder co-operation, may be understood as realized by regional and local authorities .

Taking into account the diversity of actors' activities, we are witnessing the shaping of a group of beneficiaries specializing in co-operation, both in terms of their number and the quality of realized projects. They may constitute nodes of the connection network, shaping in the area of Polish-German borderland.

From the point of view of co-operation policy, one of its most important tasks should be the shaping of new actors in two basic aspects:

- activity for the diversity of actors as regards their type and thematic scope of activities, - activating actors in areas in which they were previously poorly involved.

Excessive thematic, institutional and spatial concentration seems unfavourable from the point of view of coherent transborder region shaping.

The study showed that the type of actor, the strength of connections and thematic scope of jointly realized projects were strongly interconnected. This may significantly influence the direction in which the network of co-operation in the Polish-German borderland might evolve in the future. 


\section{REFERENCES}

Ciok, S. (2004), Pogranicze polsko-niemieckie. Problemy wspótpracy transgranicznej, Wydawnictwo Uniwersytetu Wrocławskiego, Wrocław.

Dołzbłasz, S. and Raczyk, A. (2007), New versus old cross-border cooperation programmes in the example of Polish-Czech and Polish-German border areas, Europa XXI, 16, Institute of Geography and Spatial Organization, PAS, Warszawa, 153-166.

Dołzbłasz, S. and Raczyk, A. (2010), Wspótpraca transgraniczna w Polsce po akcesji do UE, Wolters Kluwer, Warszawa.

Hall, P. (2008), Opportunities for democracy in cross-border regions? Lessons from the Oresund Region, Regional Studies, 42 (3), 423-435.

Jańczak, J. (2008), Polsko-niemieckie regiony transgraniczne i miasta transgraniczne po 2004 roku. Pomiędzy pragmatyzmem instytucjonalnym a izolacja społeczna, in: Dołzbłasz S. and Raczyk A. (eds.) Przekształcenia regionalnych struktur funkcjonalno-przestrzennych, Europa bez granic_nowa jakość przestrzeni, Rozprawy Naukowe Instytutu Geografii i Rozwoju Regionalnego Uniwersytetu Wrocławskiego, 4, Wrocław, 93-100.

Koschatzky, K. (2000), A River is a river-Cross-border networking between Baden and Alsace, European Planning Studies, 8 (4), 429-449.

OJ L 63/21, 3.3.2001, Rozporządzenie Komisji (WE) nr 438/2001 z dnia 2 marca 2001 ustanawiające szczegółowe zasady wykonania Rozporządzenia Komisji (WE) nr 1260/1999 dotyczącego zarządzania i systemów kontroli pomocy udzielanej w ramach Funduszy Strukturalnych, Załącznik IV, p. 2, 3.

Strihan, A. (2008), A network-based approach to regional borders: the case of Belgium, Regional Studies, 42 (4), 539-554.

Szmigiel, K., Dziemianowicz, W., Dołzbłasz, S., Durability of international partnerships in transborder co-operation, project financed by Ministry of Science and Higher Education (2009-2011). 
http://rcin.org.pl 